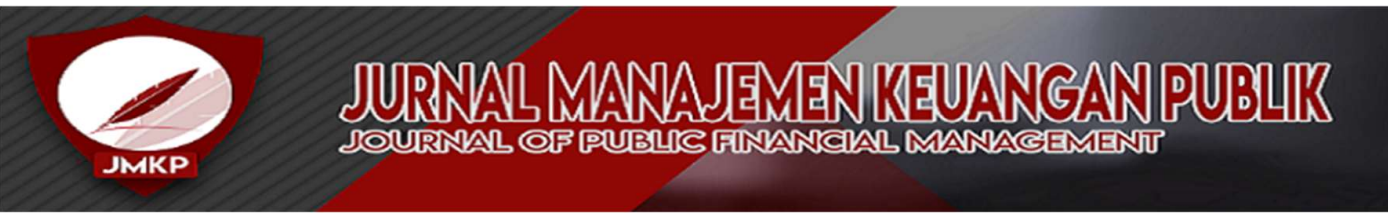

\title{
ASPEK PENILAIAN DALAM TRANSAKSI PENGALIHAN HAK ATAS TANAH DAN/ATAU BANGUNAN
}

\author{
Ferry Irawan ${ }^{1}$ \\ Politeknik Keuangan Negara STAN \\ ferry.irawan@pknstan.ac.id \\ Ferdy Subaga Benu ${ }^{2}$ \\ Direktorat Jenderal Pajak \\ ferdisubaga@gmail.com
}

\section{ABSTRACT}

This research aims to analyze the implementation of the appraisal in the transaction of transferring rights to land and/or buildings at the Ciawi Small Tax Office (STO) and identify the constraints that arise in the field during the appraisal process. This study uses a descriptive qualitative approach in order to capture the process of valuation. The results showed that implementation of the appraisal in the transaction of transferring rights to land and/or buildings at the Ciawi Small Tax Office (STO) is carried out in six steps. These steps are: (1) identification of the problem, (2) data collection, (3) data analysis, (4) application of the approaches to value, (5) final opinion of value, and (6) report of defined value.

Keywords: Property Valuation, Transfer of Rights to Land and or Building, Valuation

\section{ABSTRAK}

Penelitian ini bertujuan untuk menganalisis pelaksanaan penilaian dalam transaksi pengalihan hak atas tanah dan/atau bangunan di Kantor Pelayanan Pajak Pratama Ciawi serta mengidentifikasi kendala yang muncul di lapangan atas proses penilaian tersebut. Penelitian ini menggunakan pendekatan deskriptif kualitatif. Hasil penelitian ini menjelaskan bahwa proses pelaksanaan penilaian dalam transaksi pengalihan hak atas tanah dan/atau bangunan di KPP Pratama Ciawi dilakukan dengan enam langkah. Langkahlangkah tersebut adalah: (1) identifikasi masalah, (2) pengumpulan data, (3) analisis data, (4) penerapan pendekatan penilaian, (5) simpulan nilai, dan (6) pelaporan penilaian.

Kata Kunci: Pengalihan Hak atas Tanah dan/atau Bangunan, Penilaian, Penilaian Properti

Klasifikasi JEL: D46, E37 


\section{PENDAHULUAN}

\subsection{Latar Belakang Masalah}

Pertumbuhan penduduk di Indonesia selama dasawarsa terakhir ini mengalami kenaikan yang cukup pesat. Pesatnya laju pertumbuhan penduduk ini hampir terasa di semua kota/kabupaten di Indonesia (Siahaan, 2004), termasuk di Kabupaten Bogor. Pada tahun 2015 sampai dengan 2019, laju pertumbuhan penduduk di Kabupaten Bogor mengalami kenaikan yang cukup signifikan (Badan Pusat Statistik (BPS) Kabupaten Bogor, 2020). Bahkan, hanya dalam 5 tahun (20152019), laju pertumbuhan penduduk di Kabupaten Bogor mencapai 9,26\%.

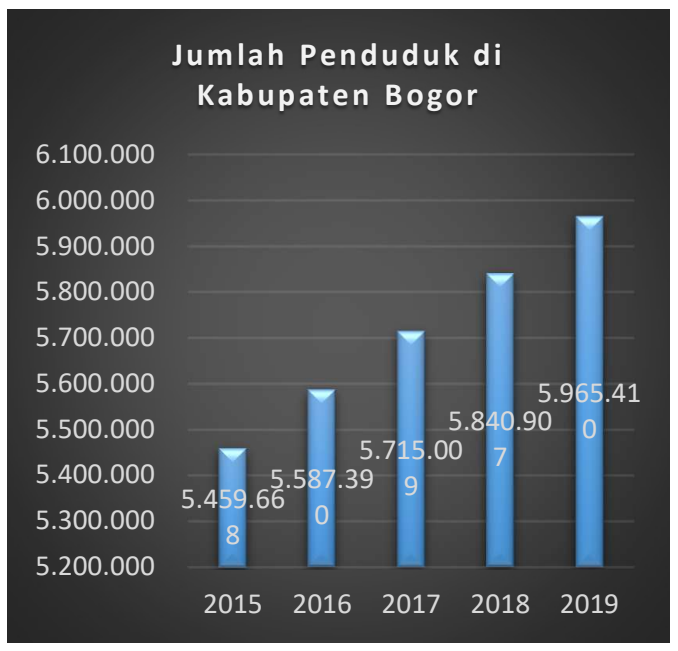

Grafik 1 Jumlah Penduduk Kabupaten Bogor

Sumber: BPS Kabupaten Bogor (2020)

Pertumbuhan penduduk yang besar dari tahun ke tahun ini memerlukan tambahan investasi dan sarana untuk mendukung kesejahteraan rakyat seperti sarana pendidikan, kesehatan, perekonomian, dan lain sebagai lainnya. Perkembangan jumlah penduduk ini juga mengakibatkan kebutuhan akan perumahan dan permukiman semakin tinggi (Prastiwi \& Utomo, 2013). Hal ini disebabkan oleh adanya pertumbuhan jumlah penduduk yang cukup signifikan yang disertai laju pertumbuhan ekonomi yang meningkat (Fahirah, 2011). Kebutuhan rumah tinggal yang semakin tinggi ini tentu berdampak pada peningkatan aktivitas bisnis terkait properti tanah, rumah dan bangunan.

Berdasarkan laporan Bank Indonesia (2019), indeks harga properti residensial di Jakarta, Bogor, Depok, Tangerang, dan Bekasi (Jabodetabek) mengalami tren yang positif sejak tahun 2016 sampai dengan tahun 2019.

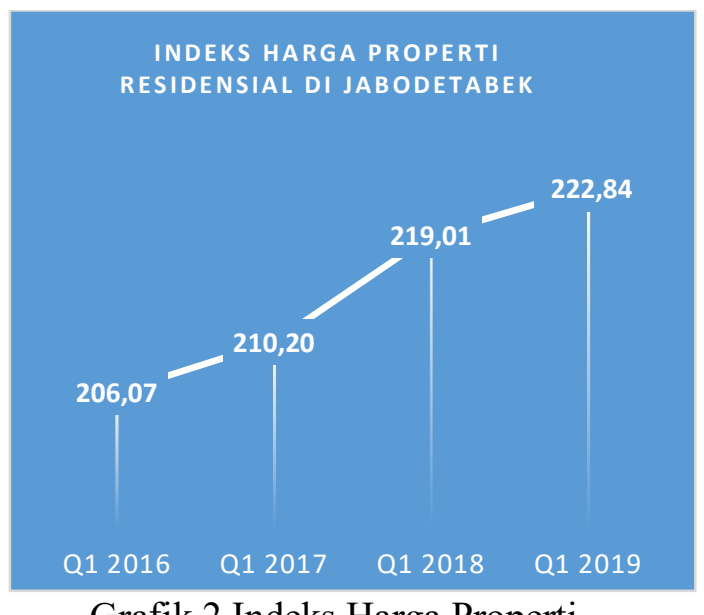

\section{Grafik 2 Indeks Harga Properti Residensial}

Sumber: Diolah dari Bank Indonesia (2020)

Adanya beban pajak yang harus ditanggung oleh wajib pajak menyebabkan sebagian wajib pajak melakukan penghindaran atau pengurangan pajak. Wajib pajak cenderung untuk mengurangi jumlah pembayaran pajak, baik secara legal maupun ilegal (Budiarto, 2018). Hal ini dapat terjadi karena kebutuhan yang lebih meningkat atau karena kesulitan keuangan maka menimbulkan tindakan untuk pengalihan (penjualan) hak atas tanah dan/atau bangunannya kepada pihak lain dengan 
menghindari/mengurangi pembayaran pajak (Handayani, 2009).

Iswara, Nahak, dan Mahendrawati (2019) menyebutkan bahwa indikasi nilai jual beli yang tidak sesuai dengan harga pasar tersebut sering ditemukan dalam proses penelitian material bukti pemenuhan kewajiban penyetoran pajak penghasilan atas penghasilan dari pengalihan hak atas tanah dan/atau bangunan. Penilaian dapat dilakukan menguji kewajaran dari transaksi tersebut (Prasetyo, 2018). Salah satu contohnya yaitu penilaian terhadap transaksi jual beli/pengalihan hak atas tanah dan bangunan. Berdasarkan Surat Edaran Direktorat Jenderal Pajak nomor SE54/PJ/2016 tentang Petunjuk Teknis Penilaian Properti, Penilaian Bisnis, dan Penilaian Aset tak Berwujud untuk Tujuan Perpajakan (selanjutnya disebut SE-54/PJ/2016), pemerintah melalui Direktorat Jenderal Pajak dapat melakukan penilaian untuk menguji kewajaran nilai pengalihan hak atas tanah dan/atau bangunan. Hal ini diperkuat dengan terbitnya Surat Edaran Direktorat Jenderal Pajak nomor SE/05/PJ/2020 tentang Prosedur Pelaksanaan Penilaian untuk Tujuan Perpajakan (selanjutnya disebut SE/05/PJ/2020), yang menyatakan bahwa Direktorat Jenderal Pajak dapat melakukan penilaian dalam hal terdapat data-data lainnya yang mengindikasikan adanya ketidakwajaran nilai transaksi pengalihan atas tanah dan/atau bangunan.

\subsection{Reviu Pustaka Terakhir}

Nilai adalah suatu opini dari keuntungan ekonomi atas suatu benda, atau harga yang paling mungkin dibayarkan untuk suatu aset dalam pertukaran, sehingga nilai bukan merupakan fakta (KP SPI dan MAPPI, 2018). Nilai juga dapat didefinisikan sebagai makna atau arti (worth) sesuatu barang (Harjanto \& Hidayati, 2014). Sehingga pendapat Harjanto dan Hidayati (2014) sesuai dengan pendapat Sujono (2012) yang mengemukakan bahwa nilai adalah kekuatan/daya tukar suatu benda terhadap benda lain yang dapat diwujudkan dalam bentuk uang. Istilah "nilai" ini biasanya menyatu dalam istilah yang lebih spesifik, seperti nilai pasar (market value), nilai investasi (invesment value), nilai wajar (fair value), dan sebagainya (Sujono, 2012).

Selain nilai, perlu juga diketahui definisi dari harga (price) dan biaya (cost) sehingga dapat diketahui perbedaan dari ketiga unsur tersebut. Masalah dapat timbul pada kata-kata yang biasa digunakan sehari-hari dalam Bahasa Indonesia namun memiliki arti yang unik dalam disiplin ilmu penilaian. Harga, biaya, dan nilai adalah suatu istilah yang saling berkaitan antara satu dengan yang lainnya, oleh karena itu seringkali terjadi salah penafsiran terhadap ketiga istilah tersebut. Untuk lebih rincinya, KP SPI dan MAPPI (2018) mendefinisikan harga dan biaya sebagai berikut.

1. Harga adalah sejumlah nominal uang yang dibayar untuk suatu benda. Harga yang dibayarkan mungkin berbeda bagi tiap individu karena tiap individu tersebut memiliki kepentingan yang berbeda-beda satu sama lainnya

2. Biaya adalah sejumlah nominal uang yang dibutuhkan untuk mendapatkan atau membuat suatu aset. Ketika aset telah didapatkan/dibuat, biaya merupakan suatu fakta. Harga memiliki hubungan dengan biaya, karena harga yang dibayar untuk mendapatkan/membuat suatu aset tersebut menjadi biaya bagi pembeli. 
Sementara itu, penilaian (appraisal) adalah "the act or process of developing an opinion of value of an assets" (Appraisal Institute, 2013), yang diterjemahkan sebagai tindakan atau proses membangun sebuah opini dari nilai suatu aset. Penilaian pada dasarnya adalah proses untuk memperkirakan nilai suatu aset jika aset itu dijual. Oleh karena itu nilai suatu aset (termasuk properti) tidak lebih dari sekadar pendapat ahli (expert opinion) semata (Adair \& Hutchison, 2005, dikutip dalam Prasetyo, 2018). Penilaian itu sendiri tidak menghasilkan fakta, hanya serangkaian perkiraan harga yang paling mungkin terjadi berdasarkan asumsi-asumsi tertentu (IVSC, 2010, dikutip dalam Prasetyo, 2018). .A State of Massachusetts (2001, dikutip dalam Kummerow, 2002) menyatakan:

"An appraisal is an unbiased estimate of the nature, quality, value or utility of an interest in, or aspect of, identified real estate....Valuation is the process of estimating market value, investment value, insurable value, or other properly defined value of an identified interest in a specific parcel at a given date".

Definisi ini menunjukkan bahwa penilai harus benar-benar memahami tujuan penilaian untuk menemukan definisi nilai yang relevan dan terlebih lagi memahami dengan benar objek yang dinilai (Kummerow, 2002). Sedangkan, properti merupakan kepemilikan seseorang terhadap suatu barang berwujud ataupun tidak berwujud. Properti yang bersifat barang berwujud adalah benda yang dimiliki oleh individu ataupun kelompok yang secara sah diakui oleh negara ataupun diakui sah secara adat. Sementara itu, properti yang bersifat tidak berwujud yaitu karya yang dibuat oleh individu maupun kelompok, seperti karya ilmiah dan sering disebut kekayaan ilmiah (Waluyo R. , 2017).
Penggunaan kata properti tanpa adanya penjelasan tambahan, dapat merujuk kepada real properti, personal properti, jenis properti lainnya seperti perusahaan/badan usaha dan HKF kombinasi darinya (KP SPI dan MAPPI, 2018).

Menurut KP SPI dan MAPPI (2018), properti dikelompokkan menjadi dua, yaitu real estat (real estate) dan real properti (real property). Penggunaan istilah real estat dan real properti memiliki pengertian yang berbeda walapun terkadang dianggap sama oleh sebagian orang awam (Aryani, 2011). Simanungkalit (2009) mendefinisikan real estat (real estate) sebagai tanah dengan semua pengembangan dan perbaikannya. Perbaikan tersebut adalah segala yang melekat atau dilekatkan pada tanah, baik dari segala perbaikan yang dibuat oleh manusia atau secara alami. Sehingga, real estat dapat diartikan sebagai tanah dan semua benda yang menyatu di atasnya (dapat berupa bangunan) serta yang menyatu terhadapnya (tiang, pohon, kolam dan lain-lain di luar bangunan). Sementara itu, definisi real properti adalah real estat beserta dengan hukum-hukum yang berhubungan, seperti sewa dan kepemilikan (Thomsett \& Thomsett, 1994). Oleh karena itu, penjabaran diatas sependapat dengan Alqarani (2020) yang menjelaskan bahwa real estat memiliki konsep yang berbeda dengan real properti. Real properti meliputi aset secara fisik ditambah dengan semua hak yang berkaitan dengan properti tersebut. Sementara itu, real estat hanya berupa fisik dari aset tersebut.

Berdasarkan definisi penilaian dan properti yang telah dijelaskan sebelumnya, maka dapat disimpulkan bahwa penilaian properti adalah proses untuk memperkirakan nilai dari suatu kepemilikan seseorang terhadap suatu 
barang berwujud ataupun tidak berwujud. Definisi penilaian properti tersebut sejalan dengan pernyataan Harjanto \& Hidayati (2014) yang menyatakan bahwa penilaian properti adalah perpaduan antara seni dan ilmu pengetahuan dalam menetukan estimasi nilai properti untuk tujuan tertentu dan pada waktu yang telah ditetapkan serta dengan mempertimbangkan segala aspek pada properti tersebut dan kondisi pasar yang terjadi.

Supriyanto (2011) menyebutkan istilah properti pada frase penilaian properti memiliki arti yang sama sebagai konsep hukum/fisik tetapi memiliki makna yang beda-beda di berbagai negara. Konsep ini dapat dibukktikan tetapi tidak terlihat. Misalnya dengan bukti pemilikan properti hak atas tanah dan/atau bangunan berupa sertifikat hak milik, sertifikat hak guna bangunan dan lain lain. Selanjutnya, dengan didasarkan pada konsep hukum tersebut (hak atas tanah), bermacam-macam aktivitas dapat dilakukan oleh pihak yang berhak atas tanah tersebut. Satu lagi istilah yang berkaitan dengan properti yaitu aset. Aset bukanlah bagian dari konsep penilaian properti akan tetapi menjadi bagian dari konsep akuntansi.

Faradina (2018) menguji proses penilaian aset dalam rangka revaluasi barang milik negara aset. Metode yang digunakan dalam penelitian ini adalah metode observasi untuk mengetahui pelaksanaan penilaian aset berupa tanah dan bangunan milik Univeritas Negeri Jakarta dalam rangka revaluasi aset. Penelitian ini menghasilkan simpulan bahwa pelaksanaan revaluasi atas tanah dan bangunan milik universitas negeri menggunakan full valuation untuk objek berupa tanah. Penilai mengunjungi secara langsung objek yang akan dinilai. Sementara itu, penilaian menggunakan desktop valuation untuk objek penilaian diluar tanah.

Heriyanto \& Mustika (2016) menganalisis proses penilaian properti rumah tinggal yang dilakukan oleh KJPP. Aksa, Nelson \& Rekan. Metode yang digunakan dalam penelitian ini adalah metode kuantitatif untuk mengetahui ada atau tidaknya kenaikan nilai properti rumah tinggal di perumahan Citraland City Samarinda pada tahun 2016 dibanding tahun sebelumnya. Penelitian ini menghasilkan simpulan bahwa penilaian properti rumah tinggal di perumahan Citraland City Samarinda menggunakan metode pendekatan data pasar dan pendekatan biaya. Properti tersebut mengalami kenaikan pada tahun 2016 dibandingkan tahun sebelumnya.

Studi untuk mengenai nilai pasar atas tanah kosong dilakukan oleh Adiyanto (2020). Studi ini menggunakan metode perbandingan pasar dan pendekatan pasar. Wicaksana \& Irawan (2021) menguji apakah nilai pengalihan tanah telah memenuhi prinsip kewajaran. Studi mengenai faktor-faktor yang memengaruhi nilai properti residensial dilakukan oleh Riyanto et al. (2021). Selanjutnya, studi yang dilakukan oleh Irawan et al. (2021) menguji proses penilaian bangunan dalam rangka pengawasan kegiatan membangun sendiri. Penelitian mengenai proses penilaian tanah dan/atau bangunan dalam rangka validasi surat setoran pajak dilakuan oleh Hidayat \& Irawan (2021). Penelitian dengan tujuan membuat model sistem pakar untuk menentukan harga pasar sebuah properti dilakukan oleh Edison, et al. (2021).

Penelitian mengenai penggalian potensi Pajak Penghasilan dari transaksi 
pengalihan hak atas tanah dan/atau bangunan dilakukan oleh Bandiyono \& Fitriyani (2021). Selanjutnya, Budiarto (2021) menguji aspek perpajakan atas pengalihan hak tanah dan/atau bangunan dengan mekanisme nominee. Selanjutnya, studi mengenai pengaturan Pajak Penghasilan atas peralihan hak atas tanah dan/atau bangunan dilakukan oleh Purnayasa, et al. (2021).

Penelitian-penelitan yang telah diuraikan di atas sebagian besar melihat dari perspektif yang berbeda. Sebagian penelitian menyelidiki bagaimana proses penilaian dilakukan. Sebagian studi membahas proses penilaian untuk transaksi yang spesifik seperti, pengalihan properti, dan lainnya. Di sisi lain, sebagian riset memfokuskan pada potensi pajak yang dapat digali dari transaksi pengalihan hak atas tanah dan/atau bangunan.

Kebaruan penelitian ini dibandingkan studi-studi sebelumnya adalah penelitian ini bertujuan untuk menganalisis proses penilaian atas transaksi pengalihan hak atas tanah dan/atau bangunan.

\section{METODE PENELITIAN}

Penelitian ini menggunakan metode Deskriptif Kualitatif. Metode tersebut digunakan untuk memperoleh gambaran yang mendalam mengenai prosedur penilaian yang dilakukan (Wahyuni, 2015). Penulis melakukan wawancara dengan fungsional Penilai pada KPP Pratama Ciawi. Selain itu, untuk lebih memberi keyakinan atas pelaksanaan penilaian, penulis juga melakukan pengamatan secara langsung ke lokasi penelitian. Pengamatan dilakukan selama dua bulan. Untuk melengkapi proses analisis, penulis juga melakukan telaah atas peraturan perundang-undangan yang berlaku.

\section{HASIL DAN PEMBAHASAN}

Berdasarkan wawancara yang penulis lakukan dengan fungsional penilai pajak KPP Pratama Ciawi, dan analisis penulis yang bersumber dari laporan penilaian tahun 2020 di KPP Pratama Ciawi, proses teknis pelaksanaan penilaian di KPP Pratama Ciawi dilakukan berdasarkan ketentuan SE54/PJ/2016. Sementara itu, prosedur penilaiannya berdasarkan ketentuan SE$05 / P J / 2020$. Selain itu, perhitungan penyesuaian dalam penentuan nilai tanah di KPP Pratama Ciawi mengacu pada ketentuan SE-14/PJ/2020. Proses pelaksanaan penilaian transaksi dalam pengalihan hak atas tanah dan/atau bangunan di KPP Pratama Ciawi adalah sebagai berikut.

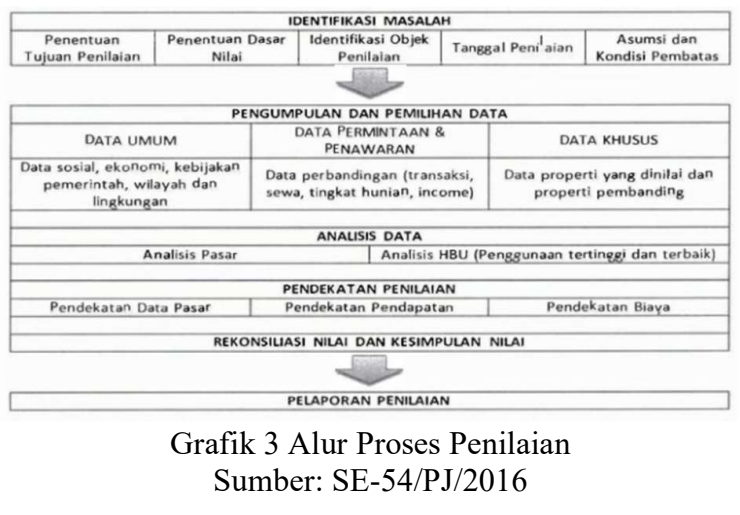

\subsection{Identifikasi Masalah}

Penilai menerima berkas permintaan bantuan penilaian yang berasal dari Seksi Pengawasan dan Konsultasi (selanjutnya disebut Waskon), Fungsional Pemeriksa Pajak, Seksi lain, dan/atau dari $\mathrm{KPP} /$ Kanwil DJP lain terkait adanya indikasi ketidakwajaran nilai transaksi 
pengalihan hak atas tanah dan/atau bangunan. Penilai melakukan identifikasi masalah berdasarkan data-data dari berkas permintaan bantuan penilaian tersebut untuk diteliti lebih lanjut. Berkas permintaan bantuan penilaian tersebut berisi nota dinas, laporan analisis ketidakwajaran nilai pengalihan, dan data-data pendukung lainnya untuk menunjang proses penilaian. Setelah menerima berkas permintaan bantuan penilaian, penilai membuat usulan surat perintah penilaian pada aplikasi naskah dinas elektronik (selanjutnya disebut aplikasi Nadine). Aplikasi tersebut merupakan aplikasi persuratan yang digunakan di lingkungan Kementerian Keuangan. Selanjutnya Kepala KPP Pratama Ciawi menerbitkan surat perintah penilaian sebagai dasar dilakukannya penilaian yang dilakukan oleh penilai.

Dalam hal diperlukan peninjauan ke lapangan, Kepala KPP Pratama Ciawi yang membawahi Penilai Pajak KPP Pratama Ciawi menerbitkan Surat Tugas untuk melakukan survei lapangan. Surat tugas tersebut berisi keterangan nama wajib pajak, nomor pokok wajib pajak dari wajib pajak, alamat objek, tujuan penelitian, jenis penilaian, dan objek penilaian.

\subsection{Pengumpulan Data}

Penilai mengumpulkan data yang berkaitan langsung dengan properti pembanding dan properti objek penilaian. Data yang dikumpulkan tersebut adalah sebagai berikut.

A. Data objek penilaian yang meliputi data terkait alamat objek penilaian, jenis penggunaan objek, luas tanah, luas bangunan, kondisi fisik bangunan, nilai pengalihan, kondisi fisik tanah, jenis hak, nomor sertifikat, tanggal sertifikat, letak kota objek, data lingkungan, jarak objek ke pusat kota, foto objek penilaian. lokasi kordinat objek penilaian, jalan utama terdekat, dan gambaran umum objek.

B. Data pembanding yang meliputi keterangan data pasar yang terdiri dari data terkait, nama pemilik properti, alamat properti, nomor telepon, sumber data, jenis data, harga transaksi/penawaran, tanggal transaksi, dan akses jalan. Selain itu, penilai mengumpulkan data terkait bumi/tanah yang meliputi data terkait jenis penggunaan lahan, luas bumi, lebar sisi depan, bentuk bumi, topografi/kontur tanah, sertifikat, kedudukan bumi, dan titik koordinat. Jika objek penilaian terdapat suatu bangunan, penilai mengumpulkan data terkait bangunan yang meliputi data luas bangunan, kondisi bangunan, jumlah lantai bangunan, perizinan bangunan, jenis penggunaan bangunan, dan foto objek pembanding. Penilai mengumpulkan data pembanding dengan kriteria.

1) Data transaksi dapat berupa data jual beli atau penawaran.

2) Waktu transaksi terjadi sebelum tanggal penilaian serta paling lama 5 tahun sebelum tanggal penilaian. Waktu transaksi diusahakan data yang terkini (mendekati tanggal penilaian).

3) Hak atas tanah diutamakan yang sama dengan objek yang dinilai.

4) Lokasi data pembanding diutamakan memiliki penggunaan yang sejenis dengan objek yang dinilai.

5) Fisik data pembanding diutamakan memiliki penggunaan 
yang sebanding dengan objek

yang dinilai.

Data pembanding yang telah dikumpulkan, diseleksi menjadi minimal 3 data yang selanjutnya dituangkan ke dalam kertas kerja untuk dianalisis lebih lanjut. Sumber data properti dapat diperoleh dari:

a) pengumpulan data internal di Direktorat Jenderal Pajak, antara lain data Sistem Informasi Direktorat Jenderal Pajak (SIDJP), Surat Pemberitahuan Tahunan (SPT), Surat Pemberitahuan Objek Pajak (SPOP), bank data pasar properti dan data perpajakan lainnya;

b) pengumpulan data eksternal antara lain data Badan Pusat Statistik (BPS), media online, dan media cetak.

c) pengumpulan data lapangan, berasal dari pelaksanaan survei lapangan.

Setelah melakukan pengumpulan data dari kantor, penilai melakukan survei ke lapangan dengan membawa surat tugas yang telah ditandatangani oleh Kepala Kantor. Adapun tujuan melakukan survei ke lapangan, antara lain:

a) melihat kondisi objek penilaian;

b) melihat kondisi lingkungan disekitar objek penilaian;

c) melihat secara langsung kondisi data pembanding;

d) melihat kondisi lingkungan disekitar data pembanding; dan

e) mencocokan kebenaran data awal dengan kondisi objek penilaian; dan mengumpulkan data dan/atau informasi lain yang berkaitan dengan objek penilaian dan/atau objek pembanding.

\subsection{Penerapan Pendekatan Penilaian}

Penilaian atas satu unit properti yang terdiri dari tanah dan bangunan dilakukan dengan menggunakan pendekatan biaya. Penjelasan narasumber adalah sebagai berikut.

"tergantung dari objek penilaian dan aspek lainnya. Jika property yang dinilai itu properti residensial, maka menggunakan pendekatan biaya”.

Penilaian dengan menggunakan pendekatan biaya dianggap pendekatan yang paling tepat untuk menghasilkan indikasi nilai pasar atas objek penilaian properti residensial karena data-data yang tersedia di pasar mendukung untuk menggunakan pendekatan tersebut dibandingkan pendekatan lainnya.

Penilaian dengan pendekatan biaya dilakukan dengan cara membagi properti menjadi dua bagian terpisah untuk dinilai masing-masing bagian sehingga menghasilkan dua nilai. Nilai yang pertama adalah nilai tanah yang dihitung menggunakan pendekatan data pasar. Nilai yang kedua adalah nilai bangunan yang dihitung menggunakan pendekatan biaya dengan metode biaya pengganti baru (new replacement cost) dikurangi dengan penyusutan. Nilai properti dihasilkan dengan cara menjumlahkan nilai tanah dengan nilai bangunan. Berikut langkah-langkah untuk menentukan indikasi nilai properti.

\section{A. Menghitung Nilai Tanah}

Perhitungan nilai tanah dilakukan dengan cara menganalisis dan melakukan penyesuaian harga data pembanding terhadap objek penilaian. Penyesuaian harga dilakukan karena adanya perbedaan 
antara variabel pembanding yang dimiliki properti pembanding dengan yang dimiliki properti objek penilaian. Variabel yang disesuaikan antara lain.

\section{1) Jenis Transaksi}

Jenis transaksi dapat berupa jual beli atau penawaran. Tetapi yang lebih diprioritaskan adalah jenis transaksi berupa jual beli karena data tersebut yang menjadi dasar untuk penentuan nilai pasar. Dalam hal jenis transaksi objek pembanding berupa jual beli, maka dilakukan penyesuaian jenis transaksi terhadap objek pembanding sebesar 0\%. Dalam hal jenis transaksi objek pembanding berupa penawaran, maka dilakukan penyesuaian terhadap objek pembanding sebesar persentase dari hasil perhitungan penyesuaian jenis transaksi. Penilai sebelumnya sudah memiliki kumpulan data terkait harga penawaran dengan harga transaksi yang terjadi (harga jual beli) dan menganalisis tren tersebut. Persentase penyesuaian jenis transaksi diperoleh dengan cara membuat rata-rata harga jual beli dibagikan dengan rata-rata harga penawaran kemudian dikurangi $100 \%$. Persentase tersebut kemudian dikalikan dengan harga properti atas tiaptiap pembanding agar memperoleh harga properti setelah penyesuaian jenis transaksi.

2) Waktu transaksi

Penyesuaian waktu transaksi dihitung dengan menggunakan teknik penggunaan data inflasi. Teknik ini menghitung penyesuaian waktu transaksi waktu transaksi berdasarkan data inflasi regional, yang secara periodic dipublikasikan oleh instansi yang berwenang seperti Badan Pusat Statistik (BPS).

3) Hak

Perhitungan penyesuaian hak atas tanah dilakukan dengan cara mengumpulkan informasi yang meliputi tarif BPHTB dan perkiraan persentase biaya pengurusan hak atas tanah dari harga transaksi. Data-data tersebut digunakan untuk melakukan penyesuaian hak atas tanah terhadap objek pembanding.

4) Lokasi dan Fisik

Penyesuaian lokasi dan fisik dapat dihitung dengan menggunakan analytic hierarchy process, yaitu suatu metode untuk pengambilan keputusan berdasarkan perbandingan variabel bobot kepentingan antar faktor lokasi dan fisik. Penyesuaian lokasi dan fisik dengan metode AHP dilakukan dengan menggunakan paling sedikit 4 faktor. Contoh faktor terkait kondisi lokasi yang mempengaruhi nilai antara lain: aksesibilitas, zoning/peruntukan, lebar jalan, dan fasilitas. Sementara itu, contoh faktor terkait kondisi fisik yang mempengaruhi nilai antara lain: penggunaan, posisi tanah, bentuk tanah, kontur/topografi tanah, dan lebar depan.

Langkah-langkah perhitungan nilai tanah menggunakan metode perbandingan jual beli harga pasar.

1) Menilai tanah dari properti tersebut seolah-olah tanpa adanya bangunan/atribut yang melekat diatasnya. 
2) Mengumpulkan minimal 3 objek pembanding yang sejenis dan sebanding dengan objek penilaian menggunakan data pasar yang terkini.

3) Melakukan penyesuaian atas datadata pembanding terhadap objek penilaian.

4) Mengestimasi nilai tanah objek penilaian.

Sehingga, nilai tanah yang diperoleh atas WP Ciawi adalah sebesar Rp 885.091.235,00-

\section{B. Menghitung Nilai Bangunan}

Perhitungan nilai bangunan di KPP Pratama Ciawi menggunakan pendekatan biaya. Nilai objek penilaian diperoleh dari penaksiran cost reproduction/ replacement new, dikurangi dengan perkiraan penyusutan. Langkah-langkah perhitungan nilai bangunan menggunakan metode biaya sebagai berikut.

1) Membuat estimasi biaya langsung dan tak langsung pada tanggal penilaian.

KPP Pratama Ciawi mengestimasi biaya langsung menggunakan biaya pengganti baru (new replacement cost) dengan teknik survei kuantitas. Penilai menghitung seluruh bahan dan tenaga kerja yang digunakan dalam konstruksi. Penilai mengunakan Kertas Kerja Penilaian Bangunan (KKP Bangunan) dalam mengestimasi biaya langsung. Terdapat 15 jenis uraian pekerjaan dalam KKP Bangunan. Penilai mengisi estimasi satuan pekerjaan di tiap jenis uraian pekerjaaan. Harga satuan yang digunakan dalam teknik ini meliputi biaya bahan dan biaya upah. Biaya penggantian baru merupakan hasil penjumlahan dari biaya satuan pekerjaan ditambah faktor keuntungan dan pajak.

Selain untuk menghitung biaya langsung, penilai juga mengestimasi besarnya penyusutan bangunan dengan teknik umur ekonomis. Perhitungan dilakukan dengan menggunakan KKP Bangunan. Penilai memasukkan data pada KKP Bangunan berupa data jenis penggunaan bangunan, tahun penilaian, tahun dibangun, tahun renovasi dan kondisi bangunan seperti contoh pada Tabel di bawah ini.

Tabel 1 Data Isian Kertas Kerja Penilaian Bangunan

\begin{tabular}{|l|c|l|}
\hline NAMA WP & $:$ & XXXXX \\
\hline NPWP & $:$ & 123123 \\
\hline PENILAI & $:$ & YYYY \\
\hline NIP & $:$ & 1980000 \\
\hline JPB & $:$ & Perumahan \\
\hline Tahun Pajak (Penilaian) & $:$ & 2020 \\
\hline Tahun Dibangun & $:$ & 2009 \\
\hline Tahun Renovasi & $:$ & 0 \\
\hline Kondisi & $:$ & Sedang \\
\hline
\end{tabular}

Sumber: Diolah dari Kertas Kerja Penilaian Bangunan (2020)

Nilai persentase penyusutan diperoleh dari daftar tabel penyusutan yang telah disusun di dalam KKP Bangunan berdasarkan data yang telah dimasukan. Setelah mengestimasi nilai penyusutan, langkah selanjutnya adalah mengestimasi nilai bangunan dengan cara mengurangkan total biaya penggantian baru termasuk pajak, dengan nilai penyusutan. Sehingga, nilai bangunan yang diperoleh dengan luas bangunan 
sebesar 133 meter per segi atas WP Ciawi adalah sebesar Rp 513.846.000,00.

\section{Menghitung Nilai Properti}

Perhitungan nilai properti berupa tanah berserta bangunan diatasnya dilakukan dengan cara menambahkan nilai tanah dengan nilai bangunan setelah dikurangi dengan penyusutan.

Tabel 2 Uraian Nilai Tanah dan Nilai Bangunan

\begin{tabular}{|c|l|c|c|c|}
\hline No. & Uraian & $\begin{array}{c}\text { Luas } \\
\text { (m2) }\end{array}$ & $\begin{array}{c}\text { Nilai / m2 } \\
(\mathbf{R p})\end{array}$ & Nilai (Rp) \\
\hline 1 & Tanah & 684 & $1,290,000$ & $882,360,000$ \\
\hline 2 & Bangunan & 133 & $3,863,504$ & $513,846,000$ \\
\hline \multicolumn{4}{|c|}{ Jumlah } & $\mathbf{1 , 3 9 6 , 2 0 6 , 0 0 0}$ \\
\hline
\end{tabular}

Sumber: Diolah penulis dari KKP Bangunan KPP Pratama Ciawi (2020)

\subsection{Simpulan Nilai}

Rekonsiliasi nilai tidak dipergunakan dalam laporan ini, karena pendekatan yang dilakukan hanya pendekatan data pasar untuk menentukan nilai pasar atas tanah saja. Sedangkan pendekatan biaya hanya digunakan untuk menghitung nilai bangunan yang berdiri di area objek penilaian. Simpulan nilai properti diperoleh dari penjumlahan hasil perhitungan nilai tanah dengan hasil perhitungan nilai bangunan. Sehingga simpulan nilai yang dihasilkan atas objek penilaian WP Ciawi adalah sebesar Rp 1.396.206.000. Pernyataan simpulan nilai dicantumkan di dalam laporan penilaian.

\subsection{Membuat Laporan Penilaian}

KPP Pratama Ciawi menggunakan laporan penilaian properti kriteria I dalam melakukan penilai properti residensial atas tanah dan bangunan sesuai dengan format laporan penilaian pada lampiran SE-54/PJ/2016. Laporan penilaian ditandatangani oleh penilai dan diketahui oleh kepala kantor. Penilai menyampaikan laporan penilaian kepada pihak yang meminta bantuan penilaian untuk ditindaklanjuti sesuai ketentuan.

\section{SIMPULAN, SARAN, DAN REKOMENDASI}

\subsection{Simpulan}

Berdasarkan penelitian yang telah dilakukan, penulis memperoleh beberapa simpulan terkait pembahasan mengenai proses pelaksanaan penilaian dalam transaksi pengalihan hak atas tanah dan/atau bangunan di KPP Pratama Ciawi. Simpulan yang diperoleh adalah sebagai berikut.

Proses pelaksanaan penilaian dalam transaksi pengalihan hak atas tanah dan/atau bangunan di KPP Pratama Ciawi dilakukan dengan enam langkah. Langkah-langkah tersebut yaitu mengidentifikasi masalah, mengumpulkan data, menganalisis data, menerapkan pendekatan penilaian, membuat simpulan nilai, dan penyusunan laporan penilaian. Penilai tidak melakukan analisis pasar dan analisis penggunaan tertinggi dan terbaik secara mendalam karena penilaian dalam transaksi pengalihan hak atas tanah dan bangunan masuk ke dalam kategori laporan penilaian kiteria I. Penilai berpendapat bahwa hal itu telah sesuai dengan lampiran SE-54/PJ/2016 terkait format laporan penilaian. Pendekatan yang digunakan dalam pelaksanaan penilaian atas transaksi pengalihan hak 
tanah dan/atau bangunan menggunakan pendekatan biaya.

Dalam pelaksanaannya, penilai menggunakan teknik umur ekonomis dalam mengestimasi besarnya penyusutan dan tidak memasukkan komponen biaya tidak langsung dalam melakukan perhitungan nilai bangunan. Tidak ada tahapan rekonsiliasi nilai dalam laporan penilaian properti atas pengalihan hak atas tanah dan bangunan di KPP Pratama Ciawi, karena pendekatan yang dilakukan hanya menggunakan satu pendekatan, yaitu pendekatan biaya.

Terdapat tiga kendala yang dihadapi oleh penilai dalam proses pelaksanaan penilaian atas tanah dan/atau bangunan di KPP Pratama Ciawi. Kendala-kendala tersebut yaitu daftar biaya komponen bangunan dalam aplikasi KKP Bangunan kurang mutakhir, sulitnya mencari data pembanding untuk sebagian objek penilaian, sulitnya mencari lokasi objek penilaian yang memiliki alamat kurang lengkap.

\subsection{Saran dan Rekomendasi}

Berdasarkan penelitian yang telah dilakukan, penulis memberikan saran terkait pembahasan mengenai proses pelaksanaan penilaian dalam transaksi pengalihan hak atas tanah dan/atau bangunan di KPP Pratama Ciawi sebagai berikut.

Melakukan updating data secara berkala atas aplikasi KKP Bangunan agar dalam penggunaan aplikasi tersebut dapat menghasilkan estimasi nilai yang lebih akurat.

Melakukan permintaan bantuan kepada ketua RT, pegawai kelurahan, atau warga di sekitar area objek penilaian untuk menunjukan letak objek penilaian terhadap objek penilaian yang memiliki alamat kurang lengkap.

Untuk penelitian berikutnya, Penulis merekomendasikan menggunakan perbandingan penggunaan pendekatan lainnya seperti; pendekatan harga pasar, pendekatan pendapatan, dan lainnya. Hal ini penting untuk mengetahui apakah terdapat perbedaan nilai yang signifikan antara pendekatan-pendekatan tersebut. 


\section{DAFTAR PUSTAKA}

\section{Buku Teks dan Artikel}

Adiyanto, M. R. (2020). Penentuan Nilai Pasar Properti Tanah Kosong di Desa Sedati Gede Sidoarjo. Media Trend, 15(2), 308-318.

Afriyandi, T. (2018). Kewenangan Pemerintah Daerah dalam Menentukan Harga Jual dalam Transaksi Jual Bel Tanah dan atau Bangunan . Jurnal Hukum Volkgeist, Vol 1, No. 2.

Alqarani, M. N. (2020). Analisis Korelasi Determinan Nilai Sewa Indekos (Studi Kasus di Kecamatan Pondok Aren, Kota Tangerang Selatan). Tangerang Selatan: Politeknik Keuangan Negara STAN.

Appraisal Institute. (2013). The Appraisal of Real Estate (14th ed.). Chicago.

Aryani, N. D. (2011). Gambaran Umum dan Perkembangan Town House Sebagai Alternatif Wujud Perumahan. Departemen Arsitektur. Depok: Universitas Indonesia.

Badan Pusat Statistik (BPS) Kabupaten Bogor. (2020). Kabupaten Bogor Dalam Angka 2019. Bogor: BPS Kabupaten Bogor.

Bandiyono, A., \& Fitriyani, M. (2021). Upaya Penggalian Potensi Pajak Penghasilan dari Transaksi Pengalihan Hak Atas Tanah dan/atau Bangunan. JABI (Jurnal Akuntansi Berkelanjutan Indonesia), 4(1), 125-138.

Bank Indonesia. (2019). Survei Harga Properti Residensial. Jakarta: Bank Indonesia.

Budiarto, M. T. (2018). Sudut Pandang Perpajakan atas Pengalihan Hak Tanah dan Bangunan dengan Mekanisme Perjanjian Nominee . Prosiding Simposium Nasional Keuangan Negara, Vol 1 No 1.

Budiarto, M. T. (2021). Tax Review Aspek Perpajakan atas Pengalihan Hak Tanah dan Bangunan dengan mekanisme Perjanjian Nominee. Journal of Tax and Business, 2(2), 4-4.Fahirah. (2011). Variabel-Variabel Penilaian Properti pada Perumahan di Palu Barat. Journal Teknik Sipil Infrastruktur, Vol 1, No 2.

Edison, M., Mayatopani, H., \& Atmojo, W. T. (2021). Sistem Pakar Penilaian Harga Pasar Sebuah Properti. Joutica, 6(2), 502-505.

Faradina, F. (2018). Tinjauan Proses Penilaian Tanah dan Bangunan Universitas Negeri Jakarta dalam Rangka Revaluasi BMN. Tangerang Selatan: Politeknik Keuangan Negara STAN.

Handayani, E. (2009). Penghindaran Pajak melalui Perjanjian Pengikatan Jual Beli dengan Kuasa Jual yang Dibuat di Hadapan Notaris di Jakarta Utara. Jurnal Studi Kenotariatan, Vol 1 No 1. 
Harjanto, B., \& Hidayati, W. (2014). Konsep Dasar Penilaian Properti. Edisi ke-2. Yogyakarta: BPFE Yogyakarta.

Heriyanto, \& Mustika, D. (2016). Analisis Penilaian Properti Rumah Tinggal di Perumahan Citraland City Samarinda pada KJPP.AKSA, Nelson \& Rekan.

Hidayat, M.Y \& Irawan, F. (2021). Pelaksanaan Penilaian Tanah dan/atau Bangunan dalam Rangka Validasi Surat Setoran Pajak: Studi pada Kantor Pelayanan Pajak Paratama Probolinggo. Jurnal Pajak dan Keuangan Negara (PKN), 3(1), 10-23.

Irawan, F., Achmadi, B., \& Wahyudi, E. (2021). Penilaian Bangunan dalam Rangka Pengawasan Kegiatan Membangun Sendiri. Jurnal Akuntansi Berkelanjutan Indonesia, 4(3).

Iswara, I. G. N. B. M., Nahak, S., \& Mahendrawati, N. L. M. (2019). Kepastian Hukum Pengenaan Pajak Penghasilan Transaksi Jual Beli Tanah dan/atau Bangunan. Jurnal Hukum Prasada, 6(1), 42-51.

KP SPI dan MAPPI. (2018). Kode Etik Penilai Indonesia dan Standar Penilaian Indonesia (Edisi VII ed.).

Kummerow, M. (2002). A Statistical Definition of Value. Appraisal Journal, 70: 407.

Permana, I. W. (2011). Analisis Implementasi Pemungutan Bea Perolehan Hak atas Tanah dan Bangunan di Kabupaten Bogor. Depok: Universitas Indonesia.

Prasetyo, K. A. (2018). Penentuan Unsur Ketidakpastian Dalam Penghitungan Estimasi Nilai Pasar Properti Dengan Menggunakan Pendekatan Pendapatan.

Prastiwi, A., \& Utomo, C. (2013). Analisa Investasi Perumahan Green Semanggi Manggrove Surabaya. JURNAL TEKNIK POMITS Vol. 2, No. 2, 191.

Pratiwi, S. I. (2020). Penentuan Besaran Nilai Pengalihan Tanah dan/atau Bangunan Dalam Rangka Pengenaan PPh Final dengan Metode Data Pasar. Tangerang Selatan: Politeknik Keuangan Negara STAN.

Purnayasa, I. K. G., Widiati, I. A. P., \& Suryani, L. P. (2021). Pengenaan Pajak Penghasilan (PPH) atas Peralihan Hak atas Tanah atau Bangunan. Jurnal Preferensi Hukum, 2(3), 519-524.

Riyanto, et al. (2021). Identifikasi Faktor-Faktor yang Mempengaruhi Nilai Properti Residensial Berdasarkan Persepsi Penilai Pemerintah INFO ARTHA, 5(1), 55-65.

Siahaan, N. (2004). Hukum Lingkungan dan Ekologi Pembangunan. Jakarta: Erlangga.

Simanungkalit, P. (2009). Menjadi Kaya Melalui Properti.

Sujono, B. (2012). Penilaian Asset dalam Sektor Properti. Modul, 11.

Supriyanto, H. (2011). Penilaian Properti Tujuan PBB. Jakarta: PT Indeks.

Thomsett, J., \& Thomsett, M. J. (1994). Getting Started in Real Estate Investing. 
Wicaksana, M. S., \& Irawan, F. (2021). Pelaksanaan Penilaian dalam Pemeriksaan Pengujian Kepatuhan Wajib Pajak: (Studi pada Kantor Pelayanan Pajak Madya Bekasi). Media Mahardhika, 20(1), 128-140.

Wahyuni, S. (2015). Qualitative Research Method: Theory and Practice. 2 ${ }^{\text {nd }}$ Edition. Jakarta: Salemba Empat.

Waluyo, R. (2017). Model Penilaian Properti Perumahan.

\section{Peraturan Perundang-undangan dan Dokumen Publik}

Republik Indonesia. 1994. Undang-Undang Republik Indonesia Nomor 12 tahun 1994 tentang perubahan atas Undang-Undang Nomor 12 Tahun 1985 tentang Pajak Bumi dan Bangunan.

Republik Indonesia. (2008). Undang-Undang Republik Indonesia Nomor 36 Tahun 2008 tentang Perubahan Keempat atas Undang-Undang Nomor 7 Tahun 1983 tentang Pajak Penghasilan.

Kementerian Keuangan. 2012. Peraturan Menteri Keuangan RI No.206.2/PMK.01/2014 tentang Perubahan atas Peraturan Menteri Keuangan Nomor 167/PMK.01/2012 tentang Organisasi dan Tata Kerja Instansi Vertikal Direktorat Jenderal Pajak.

Kementerian Pendayagunaan Aparatur Negara dan Reformasi Birokrasi Republik Indonesia. 2018. Peraturan Kementerian Pendayagunaan Aparatur Negara dan Reformasi Birokrasi Republik Indonesia Nomor 11 Tahun 2018 tentang Jabatan Fungsional Penilai Pajak.

Direktorat Jenderal Pajak. 2007. Keputusan Direktorat Jenderal Pajak Nomor KEP112/PJ/2007 tentang Penerapan Organisasi.

Direktorat Jenderal Pajak. 2020. Surat Edaran Direktorat Jenderal Pajak Nomor SE05/PJ/2020 tentang Prosedur Pelaksanaan Penilaian untuk Tujuan Perpajakan.

Direktorat Jenderal Pajak. 2020. Surat Edaran Direktorat Jenderal Pajak Nomor SE14/PJ/2020 tentang Petunjuk Teknis Perhitungan Penyesuaian dalam Penentuan Nilai Tanah untuk Tujuan Perpajakan.

Direktorat Jenderal Pajak. 2020. Surat Edaran Direktorat Jenderal Pajak Nomor SE54/PJ/2016 tentang Petunjuk Teknis Penilaian Properti, Penilaian Bisnis dan Penilaian Aset Tak Berwujud Untuk Tujuan Perpajakan. 